\title{
IN MEMORIAM \\ ILSE LEHISTE (1922-2010)
}

Long-time IPA member Ilse Lehiste died on 25 December 2010 after a brief bout with pneumonia. Her death marked the end of more than six decades of meticulous and groundbreaking research in many of the phonetic sciences and in several tangent disciplines within historical linguistics.

She was born on 31 January 1922 in Tallinn, but her family left Estonia in 1944. While living in refugee camps, she attended the University of Hamburg, earning a Doctor of Philology degree in 1948. She immigrated to the United States the following year, and held a position as an Associate Professor of Modern Languages at the Detroit Institute of Technology until she began working on her second doctorate, a Ph.D. in Linguistics from the University of Michigan. After earning that degree in 1959, she continued working as a Research Associate with Gordon E. Peterson for several more years, as they published their seminal studies of duration (Peterson \& Lehiste 1960), 'intrinsic' fundamental frequency (Lehiste \& Peterson 1961b), and amplitude variation (Lehiste \& Peterson 1961c) in the Peterson \& Barney (1952) corpus. The segmentation criteria that they developed in their study of diphthongs and glides (Lehiste \& Peterson 1961a) are still cited as a standard today.

The measurements for these studies, as well as those for her dissertation monograph (Lehiste 1960), were made using one of the few spectrograph machines then in existence. Decades later, Ilse Lehiste often described 'the special excitement that the availability of the spectrograph created - we knew that whatever we were looking at, nobody had seen before. I imagine a biologist might have felt the same way when handed the first microscope' (personal communication to John Ohala, http://ling.lsa.umich.edu/grp/phonetics_lab/history/).

In 1963, Ilse Lehiste joined the faculty in Slavic at the Ohio State University, before moving to the newly-created Department of Linguistics, where she served as its first chair from 1967 through 1971. After her retirement in 1987, she continued to make the Linguistics Department in Columbus her home base for an equally long and productive research career as Professor Emerita. She was the author, co-author, or editor of 20 books and about 200 articles. Her keynote lecture on the occasion of receiving the 2002 ISCA Medal for Scientific Achievement touched on just a few of her many contributions. Other honors that recognized her scholarship included four honorary doctorates, from Essex University in 1977, from the University of Lund in 1982, from Tartu University in 1989, and from The Ohio State University in 1999. She was a Fellow of both the Acoustical Society of America and the American Academy of Arts and Sciences, and she was elected to be a Foreign Member of both the Finnish Academy of Sciences and the Estonian Academy of Sciences.

As the title of her dissertation suggests, Ilse Lehiste made her first mark in the phonetic sciences as one of the small handful of phoneticians in North America who were already doing important foundational work on prosody in the early 1960s, a time when much of the focus on that continent was on uncovering the acoustic correlates of consonant and vowel features. While her dissertation was on English, she had also already begun the work that led to her fruitful collaboration with Pavle Ivić on the complex relationships between quantity and tone in standard Serbian (Lehiste 1961; Lehiste \& Ivić 1963) as well as her own completely soleauthored work on acoustic correlates of quantity contrasts in the Uralic languages (e.g. Lehiste 1965). Her monumental review monograph on Suprasegmentals (Lehiste 1970) summarized her first two decades of work in these areas, but it also did much more, synthesizing results from the psychoacoustics literature on the perception of pitch, loudness, and duration with results from nearly all of the then extant research in acoustic phonetics on tone, accent, and quantity.

Over the next two decades, she continued to work on the phonetics of quantity and word accent at the same time that she turned her attention to speech prosody above the word and to the ways in which sentence rhythms and melodies reflect syntactic structure and discourse 
structure. Her seminal articles and books from those decades (e.g. Lehiste 1972, 1977; Lehiste, Olive \& Streeter 1972; Lehiste \& Ivić 1986) are still cited today. She also continued to make important contributions in the area of her first doctorate. She brought her knowledge about prosody to bear on the connection between language contact and language change, as she studied and wrote about the effects of contact on a language's prosodic system, both in the Baltic Sprachbund and in the Balkans. Fittingly, two of her twenty books were textbooks on historical linguistics (Jeffers \& Lehiste 1979) and on language contact (Lehiste 1988). After her retirement and without interruption until her final short hospitalization in the last month of 2010, she continued to shape both disciplines in her work on rhythm in poetry and music and its relationship to rhythm in prose (e.g. Lehiste 2001, Lehiste et al. 2008).

Throughout her life, Ilse Lehiste influenced the field also by her admirable teaching and advising and by her championing of younger researchers. She also continued to collaborate with researchers whose expertise complemented hers in mutually beneficial ways. Two good examples are her collaboration with Robert Fox on differences between Estonian and English speakers in their perceptual weighting of cues to prominence (Lehiste \& Fox 1986) and her collaboration with Jaan Ross on many aspects of the intersection of rhythm and tune in folk music in the Baltic Sprachbund (e.g. Ross \& Lehiste 1994, 1998, 2001).

The different circumstances of these two collaborations also illustrate how European history in the 20th century both shaped and was reflected in Ilse Lehiste's personal history. The collaboration with Jaan Ross was after August 1991, when there could be more frequent travel back and forth between the U.S. and Estonia by both parties. By contrast, the collaboration with Rob Fox was during the 1980s, so it fell to Ilse Lehiste to travel to Estonia and run the tests on the Estonian speakers. On her departure, the stimulus tape was confiscated. The stimuli were pairs of noise bursts of varying length and amplitude and apparently seemed like coded messages of some kind. Her reaction was simply to smile to herself, noting what a bother it would have been if the confiscating had occurred on the way into the country but how it lightened her luggage nicely going out.

Ilse Lehiste's students describe her courses as 'fascinating, demanding, fun, rewarding'. They say such things about her advising as the following: 'Ilse's high standards always motivated and challenged me' (Sara Garnes, 'Remembering Ilse Lehiste', at http://linguistics.osu.edu/node/213). Ilse Lehiste also made invaluable contributions to education outside of her home university. These included not just her two textbooks, but also her careful selection of fundamental readings in acoustic phonetics (Lehiste 1967) that was the standard primer for a quarter of a century, until the publication of a three-volume collection by the Acoustical Society of America (Kent, Atal \& Miller 1991, Miller, Kent \& Atal 1991, and Atal, Kent \& Miller 1991).

Her students also remember her as someone possessed of a brisk self-confidence, who did what she could to inspire the same in them. "Always behave as if you were the person you want others to think you are.' was standard advice, followed by the Estonian version: 'If the dog does not hold up its own tail, who will hold it up for him?' This was particularly important advice in the early days of her research career, when opportunities for women in academia in the U.S. were rather more circumscribed than they are today.

Ilse Lehiste retained her enthusiasm for the good things of life - ideas, food, music, and travel, and the endless foibles of humans - until the last. Her hundreds of colleagues, friends, and students will always feel her loss.

Mary E. Beckman Columbus, Ohio

Linda Shockey Reading, UK

\section{References}

Atal, Bishnu S., Raymond D. Kent \& Joanne L. Miller (eds.). 1991. Papers in speech communication: Speech processing. New York: Acoustical Society of America. 
Jeffers, Robert J. \& Ilse Lehiste. 1979. Principles and methods for historical linguistics. Cambridge, MA: MIT Press.

Kent, Raymond D., Bishnu S. Atal \& Joanne L. Miller (eds.). 1991. Papers in speech communication: Speech production. New York: Acoustical Society of America.

Lehiste, Ilse. 1960. An acoustic-phonetic study of internal open juncture. Phonetica 5 (Suppl. 1), 5-54.

Lehiste, Ilse. 1961. Some acoustic correlates of accent in Serbo-Croatian. Phonetica 7, 114-147.

Lehiste, Ilse. 1965. The Function of quantity in Finnish and Estonian. Language 41, 447-456.

Lehiste, Ilse (ed.). 1967. Readings in acoustic phonetics. Cambridge, MA: MIT Press.

Lehiste, Ilse. 1970. Suprasegmentals. Cambridge, MA: MIT Press.

Lehiste, Ilse. 1972. The timing of utterances and linguistic boundaries. Journal of the Acoustical Society of America 51(6B), 2018-2024.

Lehiste, Ilse. 1977. Isochrony reconsidered. Journal of Phonetics 5(3), 253-263.

Lehiste, Ilse. 1988. Lectures on language contact. Cambridge, MA: MIT Press.

Lehiste, Ilse. 2001. Prosodic change in progress: From quantity language to accent language. In Johanna Paula Monique Fikkert \& Haike Jacobs (eds.), Development in prosodic systems, 47-66. Berlin: Mouton de Gruyter.

Lehiste, Ilse \& Robert Allen Fox. 1986. Perception of prominence by Estonian and English listeners. Language and Speech 46, 375-401.

Lehiste, Ilse \& Pavle Ivić. 1963. Accent in Serbo-Croatian: An experimental study (Michigan Slavic Materials 4). Ann Arbor, MI: Department of Slavic Languages and Literatures.

Lehiste, Ilse \& Pavle Ivić. 1986. Word and sentence prosody in Serbocroatian. Cambridge, MA: MIT Press.

Lehiste, Ilse, Joseph P. Olive \& Lynne A. Streeter. 1972. Role of duration in disambiguating syntactically ambiguous sentences. Journal of the Acoustical Society of America 60(5), 1199-1202.

Lehiste, Ilse \& Gordon E. Peterson. 1961a. Transitions, glides, and diphthongs. Journal of the Acoustical Society of America 33(3), 268-277.

Lehiste, Ilse \& Gordon E. Peterson. 1961b. Some basic considerations in the analysis of intonation. Journal of the Acoustical Society of America 33(4), 419-425.

Lehiste, Ilse \& Gordon E. Peterson. 1961c. Vowel amplitude and phonemic stress in American English. Journal of the Acoustical Society of America 33(4), 428-435.

Lehiste, Ilse, Pire Teras, Valts Ernštreits, Pärtel Lippus, Karl Pajusalu, Tuuli Tuisk \& Tiit-Rein Viitso. 2008. Livonian prosody (Suomalais-Ugrilaisen Seuran Toimituksia 255). Helsinki: SuomalaisUgrilainen Seura.

Miller, Joanne L., Raymond D. Kent \& Bishnu S. Atal (eds.). 1991. Papers in speech communication: Speech perception. New York: Acoustical Society of America.

Peterson, Gordon E. \& Harold L. Barney. 1952. Control methods used in a study of the vowel. Journal of the Acoustical Society of America 24(2), 175-184.

Peterson, Gorden E. \& Ilse Lehiste. 1960. Duration of syllable nuclei in English. Journal of the Acoustical Society of America 32(6), 693-703.

Ross, Jaan \& Ilse Lehiste. 1994. Lost prosodic oppositions: A study of contrastive duration in Estonian funeral laments. Language and Speech 37(4), 407-424.

Ross, Jaan \& Ilse Lehiste. 1998. Timing in Estonian folk songs as interaction between speech prosody, meter, and musical rhythm. Music Perception: An Interdisciplinary Journal 15(4), 319-333.

Ross, Jaan \& Ilse Lehiste. 2001. The temporal structure of Estonian runic songs. Berlin: Mouton de Gruyter. 